\title{
Open Innovation in the Food and Beverage Industry
}

\begin{abstract}
Purpose: The aim of this paper is to extend our knowledge into the relationship between open innovation and firm innovative performance. Specifically, we aim to determine whether the benefits of OI practices are different for Food and Beverage (FnB) firms as compared to those of other sectors. The FnB industry is relevant in terms of employment GDP generation in the UE, characterised by high integration and low-tech intensity.

Methodology: In order to achieve our goal and obtain robust results, we consider four open innovation dimensions and four innovation performance measures using panel data (2004-2011) from 10,771 FnB and non-FnB firms using Tobit and Logit models by random effects.

Findings: We test and confirm the presence of the classical inverted U-shape relationship between $\mathrm{OI}$ and firm innovative performance for $\mathrm{FnB}$ and non-FnB companies. However, the optimal number of external sources of knowledge used is lesser for FnB than the rest of the companies.

Originality: The article compares the OI effects in a tradicional and low-tech industry vs other industries considering four innovation outputs (product innovations, process innovations, incremental and radical innovation).
\end{abstract}

Keywords: Open Innovation, Innovation Performance,.

JEL code: M21, O32, Q16 


\section{Introduction}

Traditionally, firms have innovated by looking in-house for new ideas, technologies, products and processes that could give them sustainable competitive advantages. The limitation of these exclusively internal activities is that firms miss out on ideas, knowledge and technology storage beyond their limitations. However, some firms are aware of these boundaries and have shifted from a closed innovation strategy to an open innovation strategy (hereafter "OI"), a term coined by Henry Chesbrough in 2003. The basic idea behind OI is that firms should combine internal and external ideas and technologies when innovating.

Previous research suggests that OI practices can increase a firm's return on innovation. It has been shown, for instance, that OI can contribute to gaining knowledge, reducing costs, shortening time to market, enhancing innovation performance and increasing sales (Huizingh, 2011; Laursen and Salter, 2006; Tomlinson, 2010). The question to be addressed is how OI could affect innovation performance depending on each particular external environment.

In line with the aforementioned question, this paper focuses on the effects of OI practices on innovation performance by analysing behaviour differences in the traditional food and beverage (FnB) industry versus other industries. Although usually regarded as a low-intensity innovation businesses (García-Martinez and Burns, 1999; Grunert et al., 2008; Capitanio et al., 2009 and 2010;), FnB firms show particular features which make them more vulnerable in the context of a global, changing and unstable environment characterized, among others factors, by a dependence of the production process on uncontrollable factors such as perishability of products and raw materials. This sector has further characteristics such as vertical integration along the industry value chain, many actors in different areas who establish a variety of links and networks, and fast-paced technological changes which favour cooperation and the development of OI practices (Sarkar and Costa, 2008, Arranz and Fernández de Arroyabe, 2008, Fortuin and Omta, 2009 and Noordman and Meijer, 2013). 
In order to ensure a wider panorama we use two different types of innovation performance measures. The first is related to the nature of the innovation output, that is, whether it involves a new process or a new product. The second involves the innovation novelty level, i.e., the percentage of sales due to products that are new to the market and the percentage of sales due to products that are only new to the firm. Neither of these innovation-output measurement options is new to the FnB sector, which previous research has found to produce proportionally more process innovations than product innovation (Beckeman and Skjöldebrand, 2007; Capitanio et al., 2010). However, product innovations have recently increased in importance and tend to lean more towards incremental innovation rather than radical innovation (Galizzi and Venturini, 1996; Grunert et al., 1997; Alarcón and Sánchez, 2013).

This study uses panel data on Spanish firms covering the 2004-2011 period. The data is drawn from the Spanish Community Innovation Survey (CIS), which follows the guidelines of the Oslo Manual (OECD, 1997). The estimation of Tobit and Logit models with random effects enables both adjustment for endogeneity and inference of causal effects.

The remainder of the paper is structured as follows. Following the Introduction, Section 2 presents a description of innovative behaviour in Spanish food firms. The theoretical background and the effects of OI on innovation performance are presented in Section 3. The data and variables are described in Section 4, and Section 5 provides the openness results on firm innovative performance. The last section presents the conclusions, contributions and implications, noting the limitations of the study.

\section{The food sector and innovation}

The FnB industry is the largest manufacturing sector in the EU in terms of turnover (14.9\%) and value added (12.9\%) (Food Drink Europe, 2013-2014 report). Furthermore, this sector accounts for 
the top manufacturing activity in terms of turnover in several Member States such as France, Spain and the UK (Food Drink Europe, 2012). In the Spanish case, it accounts for 9.6\% of total manufacturing turnover. In terms of structure, it is heavily weighted towards micro-firms (78\%). Small companies represent $18 \%$ and the remaining $4 \%$ are medium and large (Eurostat, 2015). ${ }^{1}$ The importance of this sector becomes even greater when we consider its contribution to the development of rural areas in Spain (Arnalte and Ortiz, 2011) as well as its high level of strength in times of crisis when compared to other productive sectors (OECD, 2009).

It is a fragmented industry with more than 280,000 firms with an R\&D investment of $0.53 \%$ in terms of turnover. In this sense, according to Acosta et al. (2013), the FnB industry is a mature and relatively low-technology sector dominated by smaller firms as opposed to multinational companies. Against this background, innovation is one of the most important factors enabling firms to challenge major competitors in both national and international markets (Rama, 1996, 2008; Grunert et al., 1997; Capitanio et al., 2009). In more specific terms, innovation trends in the food sector are geared toward sustainability, a bio-based economy, health, biotechnology and the effects of climate change (Boehlje et al., 2011, Lybbert and Sumner, 2012). These trends have been highlighted by a number of authors who insist on the possibility of structural change in this sector (Sarkar and Costa, 2008 and Seifoldin et al., 2008, among others). An important change in trend has been identified by Fortuin and Omta (2009) as 'chain-reversal', since the sector is moving from a supply-driven approach to a demand-based approach. Various authors are working on the importance of consumer drive for innovation (Grunert et al, 2008, Sarkar and Costa, 2008, Fortuin and Omta, 2009, OECD, 2014, among others).

In terms of type of innovations developed, a further impact on the behaviour of FnB firms is the fact that this sector's innovations are predominantly incremental rather than radical (Galizzi and

\footnotetext{
${ }^{1}$ Based on the European Commission's classification (2005) which defines SMEs as firms with less than 250 employees and total assets of less than EUR 43 million.
} 
Venturini, 1996, Grunert et al, 2008). They mostly comprise improvements or variations of existing products, and patented food technology is highly concentrated. The reason for the predominantly incremental nature of innovation is related to demand constraints and conservative consumer behaviour. However, here we note that this traditional stability in the sector is likely to undergo an important trend change in terms of both complexity and ways of innovation which could result in an increase in the number or radical innovations, for instance, an area where collaborative options show good results (Bigliardi and Galati, 2012; García et al., 2014).

In short, various factors favour the use of OI options and may lead this sector to show more interest in these innovative development paths. These factors include intense collaboration along the industry value chain (agriculture, food processing and distribution), the pace of technological change, a mature market, intensive competitiveness and the small company size of a large part of its productive fabric (García et al., 2014). This is highlighted by various authors who have studied the effect of OI practices in firms either through case studies (Vanhaverbeke et al., 2007; Sarkar and Costa, 2008; Fortuin and Omta, 2009; Bigliardi and Galati 2012, and others) or using larger samples (Alarcón and Sánchez, 2013; Acosta et al., 2013; Bayona et al., 2013; García et al., 2014, and others). These studies show that OI is the appropriate paradigm for addressing the new challenges faced by the FnB industry.

\section{Theoretical background and hypotheses}

Innovation processes are systemic and interactive in nature. Companies therefore hardly ever innovate on their own but rather in cooperation with various agents. Research on this interactive process has increased after Chesbrough's (2003) publication. $^{2}$ There are various definitions of OI. ${ }^{3}$ Here we will use the one by the pioneer of the concept: "Open Innovation is the use of purposive

\footnotetext{
${ }^{2}$ According to the ISI Web of Knowledge, the number of articles in the OI field was 26 in 2006, 75 in 2008,191 in 2009 and 137 in 2012.

3 For an extensive literature review see Gianiodis et al., (2010).
} 
inflows and outflows of knowledge to accelerate internal innovation, and expand the markets for external use of innovation, respectively" (Chesbrough et al., 2006).

Researchers who have reviewed the emerging findings in OI (e.g., Dahlander and Gann, 2010; Gianiodis et al., 2010; Huizingh, 2011; Lichtenthaler, 2011) have pointed out that it is a broad concept and that most studies distinguish between inbound and outbound open innovation activities. While outbound activities are defined as the flow of knowledge which goes from inside to outside the firm (e.g., patents, licenses and start-up companies), the inbound activities stress that firms can actively search for new technologies and ideas beyond their boundaries and combine them with internal knowledge and technologies to achieve new products, processes and technologies and reduce time to market (Spithoven et al., 2010). These activities comprise exploring knowledge through integration of ideas, acquisition of patents and other technologies and joint development of innovation processes through alliances and partnerships. Gassman and Enkel (2004) point out that while companies which choose the outbound process as their key process are mainly basic researchdriven companies with wide-ranging applications, companies that choose the inbound process are mainly in low-tech industries. The FnB industry is classified as low tech by the OECD, which substantiates a focus on inbound activities for these companies.

Research suggests that inbound OI practices can increase a firm's return on innovation (Huizingh, 2011; Laursen and Salter, 2006; Tomlinson, 2010). However, following Gassman and Enkel (2004), in order to make the most of the inbound activities, firms need to be able to understand and integrate the external knowledge into the firm's routines (i.e., absorptive capacity). This is particularly relevant, and challenging, in low-tech sectors such as FnB, given that absorptive capacity is achieved mainly through internal R\&D activities (Cohen and Levinthal, 1990).

Figure 1 illustrates the model proposed in this article based on the conceptual models put forward by Vanhaverbeke et al. (2007) and Fortuin and Omta (2009) for the FnB sector. We believe that the adoption of inbound OI combined with firms' internal R\&D resources will increase the innovation 
performance of FnB companies. In line with other studies (Bayona and García-Marco, 2010; Alarcón and Sánchez, 2013), we think that inbound OI activities will not have an immediate effect on firms' innovative performance but that this will be observed later in time. The active search for innovation ideas and the joint implementation of innovation projects with other partners will require time to mature before their effect materializes in product or process innovations or in sales of innovative products. Inbound OI activities, both idea searching and alliances, are dynamic capacities which strengthen a firm's internal competencies and help sustain competitive advantages (Eisenhardt and Martin, 2000; Sarkar and Costa, 2008; Ebersberger et al., 2012).

\section{INSERT FIGURE 1 HERE}

We used various innovation performance measures and various inbound OI practices to contrast this model and obtain a wider perspective of the OI phenomenon. The first innovation performance measure is product innovation, which is the most common one used in studies evaluating the effect of OI (i.e., Veugelers and Cassiman 2009; Tsai and Wang. 2009). The second one, less used in OI literature, is process innovation. We also selected this measure because, as stressed before, previous studies have shown that FnB firms tend to innovate more in processes than in products (Capitanio et al., 2010). The third one relates to product novelty level, which we define as the percentage of newto-market products (radical), versus the percentage of products that are only new to the firm (incremental). These measures are important because they measure the success (market acceptance) of innovation outputs.

Inbound Open Innovation is not a single best practice but rather a set of differentiable practices. In line with other research (Ebersberger et al., 2012, Laursen and Salter, 2006), this paper identifies different dimensions of OI: the relative importance of the various external information sources used to innovate; the cooperation agreements the firm has entered into for innovation purposes and the externalisation of $R \& D$ activities.

\subsection{External sources of knowledge}


Our first OI dimension involves mechanisms which expose firms to new information and novel ideas from outside sources. A firm interested in innovations is more likely to be involved in the active use of information, but the role of external channels might differ according to the type of innovation involved (Lee et al., 2010).

We use OI breadth and OI depth, terms coined by Laursen and Salter (2006), to define the diversity and intensity, respectively, of information-finding activities. External sources of innovation such as customers, suppliers, competitors and universities can be considered the main elements of a firm's search strategy. Previous studies have recognised the strategic importance of a wide range of knowledge sources for driving innovation (Laursen and Salter, 2006; Sofka and Grimpe, 2010), and for achieving not only product but also process innovations (Huang and Rice, 2012). In their paper focused on SMEs, Lee et al. (2010) find that breadth is more closely linked to product innovation than depth, and while breadth correlates positively with process innovation, depth does not.

Other studies analyse the effect of external sources of knowledge on novelty of innovation. Chiang and Hung (2010) hypothesise that intensive exploitation of knowledge from a limited number of external sources (high level of depth) will have a positive impact on incremental innovation. Exploitative learning involves refining and deepening existing knowledge to enrich current innovations. Accessing knowledge from a broad range of external channels (high level of breadth), on the other hand, will relate positively to radical innovation (Chiang and Hung, 2010). Exploratory learning refers to the pursuit of knowledge leading to further variations, potentially increasing customer value, and driving radical innovation. Finally, Sofka and Grimpe (2010) find that the use of several sources of external knowledge impacts positively on radical innovation.

Although Laursen and Salter (2006) generally observe a positive effect of external knowledge sources on firm innovative performance, they also find that when used in excess OI has a negative impact i.e., a curvilinear relationship (inverted U-shape). This shape is explained by several factors. First, absorption of external knowledge is subject to uncertainty since managers can at times find it 
difficult to ascertain which external source will be the most useful for any given innovative project. When many sources are used, unrewarding experiences increase. Second, firms sometimes fall into the trap of over-searching for external knowledge, which can result in an excess of ideas eventually leading to time and management problems affecting innovative performance. However, sectors with low-tech opportunities, such as the FnB industry, are likely to present fewer incentives to search for external sources of knowledge (Laursen and Salter, 2006) and a greater increase of cost linked to the information excess. Since FnB firms would lack absorptive capacity due to the low amount or internal R\&D, the inverted U-shape effect caused by excess information sources will present the threshold with a lesser number of external sources compared to the rest of companies.

This leads us to pose the following hypotheses:

H1a: The use of external knowledge sources will result in an inverted U-shape on firm's innovative performance.

H1b: The use of external knowledge sources in the FnB industry will result in an inverted U-shape on firm's innovative performance, but the optimal number of external knowledge sources will be lesser.

\subsection{Cooperation agreements}

The second dimension for measuring openness is innovation-focused cooperation agreements. Unlike previous measures, this one refers to active cooperation with other agents engaged in innovative activities, which will also bring a flow of new knowledge into the firm. The complex nature of the innovation process makes it increasingly necessary for firms to cooperate with other organisations in order to carry through their research and development initiatives. Therefore, the more intensely the company interacts with these external agents through cooperation agreements, the more likely it is to learn about new opportunities. 
Previous research suggests that a firm can improve its innovation performance by interacting with different partners. Tomlinson (2010) finds that inter-firm collaboration with suppliers, buyers and competitors drives product and process innovation. Belderbos et al. (2004) find that R\&D cooperation has a positive effect on innovative performance, although the impact varies according to the type of partner. Regarding innovation novelty level, Nieto and Santamaría (2007) indicate that firms receiving information through collaboration with various partners are better positioned to produce more radical and novel innovations. Their results show that diversity in collaboration is always positive — both for radical and incremental innovation — but that its impact on radical innovations is higher.

Nevertheless, a number of alliance scholars (Hoffmann, 2005) note that when the number of partners is high and the complexity of an alliance portfolio increases, the firm will have to use more resources to manage this alliance, which could have a negative impact on performance. The arguments put forward to construct hypothesis 1a in relation to agents' bounded rationality are valid in the case of formal cooperation agreements. In addition to these reasons, as noted by Faems et al., (2010), the adoption of a diverse technology alliance portfolio requires a wide variety of alliance management skills that companies often do not have, such as dedicated alliance managers on payroll. This can lead to an excess of resources allocated to alliances management, which in turn can weaken the results of the innovation action. In other words, the excessive use of cooperation agreements has a negative impact on a firm's innovation performance.

Cooperation activities do take place within traditional and mature sectors, such as the food industry. Sarkar and Costa (2008) suggest that innovation activities have to be carefully coordinated due to the number of actors from different sectors involved in food production, coupled with the heterogeneous requirements of intermediate customers, end users and legislators. Furthermore, many of the emerging technologies related to new food applications (e.g., nanotechnology) are being developed outside the processing industry. In order to leverage these ongoing innovation 
processes, food industry actors must therefore enter into formal arrangements with other entities in the innovation system. Finally, the establishment of close relationships with other agents (regulatory bodies, intermediaries and end users) throughout the innovation process is essential to improve the public acceptance of emerging food technologies and the commercial success of resulting products (Costa and Jongen, 2006; Vanhaverbeke and Cloodt, 2006). Thus, as in other industries, we could expect a positive effect on innovation performance of cooperation agreements in FnB firms. However, since it is a low technology intensity industry, the need for cooperation is lower than in other, more technology-intense industries where the use of outside sources is more frequent to boost product development in environments where fast-paced technology changes is the norm (Manzini et al., 2016). We therefore believe that this collaboration need faced by FnB firms, although positive, will be lower than with other companies. And given the increased cooperationrelated management costs, the optimal number of partners will be lower than for more high technology intensity firms.

On the basis of the above evidence, we propose the following hypotheses:

H2a: The establishment of formal cooperation agreements with different partners will result in an inverted U-shape for firms' innovation performance.

H2b: The establishment of formal cooperation agreements in FnB firms with different partners will result in an inverted U-shape on firms' innovation performance but the optimal number of formal cooperation agreements sources will be lesser.

\subsection{Expenditure on External $R \& D$}

The third dimension of OI is the percentage of innovation expenditure allocated to external R\&D activities to represent the degree of openness in R\&D activities, one of the most important aspects of innovation. Since external R\&D is generally used in a more selective and partial fashion, Huang and Rice (2012) hold that it has a weaker impact on innovation performance than the other two OI dimensions. 
Some studies (Chen and Yuan 2007; Santamaría et al., 2009, among others) argue that the acquisition of R\&D and technology is less effective than the in-house or combined (in-house and external) strategies when achieving product and process innovations and sometimes has a negative impact (Jones et al., 2001; Fey and Birkinshaw, 2005, among others). Cruz-Cázares et al. (2010) find that in low technology intensity sectors, such as the FnB industry, total reliance on external R\&D has a positive effect on process innovations but not on product innovations. However, they show that when combined with in-house $R \& D$ it has a positive effect on both types of innovation. With respect to innovation novelty level, Beneito (2006) finds the externalisation of R\&D activities has a positive effect on incremental innovations.

According to Berchicci (2013), externalisation of R\&D has an inverted U-shape relationship on innovative performance. Firms are able to improve their innovation performance by externalising R\&D activities to a moderate degree, whereas firms relying more heavily on external than on internal $\mathrm{R} \& \mathrm{D}$ witness a decline in their innovative performance, measured by the share of turnover from new or significantly improved products. Relying heavily on external technology sourcing increases searching, coordinating and monitoring costs and could hamper the building of pathdependent knowledge stocks within the firm.

The Alarcón and Sánchez (2013) study, focusing on the food sector, concludes that external R\&D has a positive effect on business performance in the medium term and, as with other companies, excessive investment on external technology sources would increase coordination problems and control costs, triggering a drop in innovative performance.

Based on the foregoing evidence, we propose the following hypotheses:

H3a: The externalisation of R\&D activities will result in an inverted U-shape for firms' innovation performance

H3b: The externalisation of R\&D activities in FnB firms will result in an inverted U-shape for firms' innovation performance, but the optimal degree of R\&D externalisation will be lesser. 


\section{Absorptive capacity}

It is important to highlight the fact that the OI approach does not lead firms to rely exclusively on external knowledge but rather to combine it with their own knowledge. Several authors (Chesbrough, 2003; Berchicci, 2013) describe OI as engagement with external knowledge sources rather than total reliance on them. Firms that do not develop internal R\&D and depend entirely on external sources and partners could have a low ability to fully capture and assimilate external knowledge.

Absorptive capacity highlights the complementarity between open and closed strategies. AbecassisMoedas and Mahmoud-Jouini (2008) define absorptive capacity as a firm's ability to recognise the value of external knowledge and to assimilate and apply it to commercial ends. It is through inhouse $R \& D$ activities that firms enhance their opportunities to scan and integrate external knowledge. Investment in R\&D increases absorptive capacity and enables firms to benefit from a larger set of diverse sources of knowledge.

Therefore, in line with other studies (Laursen and Salter, 2006; Sofka and Grimpe, 2010; Huang and Rice, 2012; Berchicci, 2013) we argue that firms need to have the correct amount of absorptive capacity in order to reap returns for their OI strategy.

\section{Methodological strategy}

The database used for this paper is the Spanish Technological Innovation Panel (PITEC) survey, a data panel covering the 2004 to 2011 period. It was compiled by the Spanish National Statistics Institute (INE) in collaboration with the Spanish Science and Technology Foundation (FECYT) and the Foundation for Technological Innovation (COTEC). ${ }^{4}$ PITEC is designed as a panel survey and

\footnotetext{
${ }^{4}$ Available to researchers at the FECYT site: http://icono.fecyt.es/contenido.asp?dir=05\%29Publi/AA\%29panel. PITEC started with two samples with data from 2003: a sample of firms with 200 or more employees and a sample of firms with internal R\&D expenditures. In 2004, the database included a sample of firms with fewer than 200 employees,
} 
compiles the information provided by the Spanish Community Innovation Survey (CIS), which follows the Oslo Manual guidelines (OECD, 1997).

The total sample includes 75,594 observations from 13,553 Spanish firms. After filtering for outliers and missing values, our final sample covers 63,337 observations which correspond to 10,771 firms.

The PITEC dataset includes extractive, agri-food, manufacturing and service firms. The food industry comprises CNAE-2009 codes 10, 11 and 12 (food, beverages, and tobacco) and accounts for $7.17 \%(4,539$ observations $)$ of the total sample.

\subsection{Dependent variables}

Based on our sample data we constructed our first measure of innovative performance using two dummy variables which take a value of 1 if the firm has achieved product (or process) innovation, and zero otherwise. According to the Spanish centre for sociological research (CIS), product innovation is understood as the introduction into the market of a new product or service or a significantly improved product or service in terms of capabilities, user-friendliness, components or sub-systems. A process innovation is the implementation of a new or significantly improved production process, distribution method or support activity for a firm's products or services. Due to the dummy characteristics of the variables, we will estimate the effect of OI on these variables using random-effect Logit models in order to control for heterogeneity across units in the panel.

For the third proxy of innovation performance, we use the share of sales due to new-to-the-market products (i.e., radical innovations). Finally, PITEC also has information on the share of sales gained through new-to-the-firm product innovations (i.e. incremental innovations). These indicators of innovative performance do not merely measure the innovations achieved but also the successful 
innovations that reached the market and have been used extensively in the literature (e.g., Veugelers and Cassiman, 2006; Tsai and Wang, 2009). Since these two performance variables are percentage measures that by definition are conditioned on values between $0 \%$ and $100 \%$, they are both left and right censored. Therefore, random-effect Tobit regression models are used to test our hypotheses about how they are affected by OI practices.

\subsection{Independent variables}

\subsection{Measuring open innovation}

It is worth mentioning that all independent and control variables are lagged by one period to be consistent with the survey implementation rhythm and avoid simultaneity and reverse causality problems which are quite common when using CIS data (Mairesse and Mohnen, 2010). By doing so, we will be capable of observing the real causal inferences (Baum, 2006). Lagged-variable models have been shown to possess superior predictive validity, particularly when measuring innovative outcomes (Bradley et al., 2010).

\subsubsection{External knowledge sources}

We here use the concepts which Laursen and Salter (2006) defined as breadth and depth and which had been extensively used in the OI literature. Breadth refers to the scope of external search, which is defined as the number of external information sources used by firms in their innovation activities. The second concept, depth, is defined in terms of how deeply firms draw on their various external information sources.

Our database features items that capture information sources used throughout firms' innovation activities. Respondents are requested to estimate the importance of ten different sources for their firms using a four-point Likert scale ranging from 0 ("not used") to 5 ("very important"). These sources are clients, suppliers, competitors, private laboratories and consultants, universities, public research centres, technological centres, conferences and trade fairs, journals and scientific papers and industry associations. The breadth variable is constructed from a combination of the ten 
aforementioned sources of innovation information. Each source is coded as a binary variable where 0 means "not used" and 1 means "used". The source codes are then added up to obtain the value of the breadth variable, which ranges from 0 to 10 , where 0 represents non-usage, and 10 stands for usage of all the external information sources mentioned.

Depth takes into account the same knowledge sources. In this case, a source is coded 1 if rated "very important", and 0 otherwise. The ten source codes are then added up to obtain the depth variable value, which, again, ranges from 0 to 10 , where 0 indicates no intense use of any external knowledge source, and 10 indicates intense usage of all 10 external knowledge sources. Firms reporting intense usage of a greater number of information sources are assumed to be more open than the rest in terms of search depth.

\subsubsection{Cooperation agreements}

The second dimension, cooperation, is captured by means of the corresponding survey question, which asks whether the firm has carried out innovation projects in cooperation with other agents, and, if so, what type of partner was involved. In order to highlight the mutually interactive nature of cooperative innovation, the questionnaire explicitly describes it as "active participation with other firms or non-commercial institutions in innovation activities". This excludes mere contracting-out of work with no active co-operation. Potential partners include other companies within the firm's business group, suppliers, clients or customers, competitors, consultants, commercial labs and private $R \& D$ institutions, universities and other centres of higher education, public research organisations and technology centres.

The cooperation breadth variable was constructed by following the same strategy used for external information sources. In other words, we added up the scores of binary variables used to capture cooperative innovation activities with each type of partner. A firm cooperating with eight different partners is assigned a score of eight on the cooperation breadth variable. The score for a firm with no cooperation agreements for innovation would be zero. 
This second dimension of the degree of firms' openness seems to capture an entirely different element when compared to the breadth of external information sources.

\subsubsection{External Innovation Expenditure}

The third dimension of Open Innovation is expenditure on external innovation. We include a measure for the percentage of innovation expenditure allocated to external R\&D, which includes R\&D services, but not machinery, equipment and training costs.

\subsubsection{Absorptive Capacity}

As mentioned before, firms that achieve OI practices should have dynamic capabilities for researching, identifying and assimilating external knowledge. In line with Escribano et al. (2009), we measured absorptive capacity as the factor loading of internal R\&D expenditures, percentage of innovation expenditures dedicated to training employees, ${ }^{5}$ type of $\mathrm{R} \& \mathrm{D}$ (occasional or continuing) and the percentage of employees dedicated to R\&D activities). The KMO test $(0.766)$ indicates that the factor generated is adequate.

\subsection{Control variables}

We also control for the ratio of innovation expenditure to total sales (Innovation expenditure). According to CIS, innovation expenditure items include in-house and external R\&D, the acquisition of machinery, equipment and software, the acquisition of external knowledge, innovation-oriented training, and costs incurred through the market introduction of innovation outputs. Finally, we control for firm size, measured as the natural logarithm of number of employees.

The model also includes the dummy variable food, which takes the value of 1 when the firm is in the food sector and zero for the rest of sample. Finally, year dummies are applied to control for

\footnotetext{
${ }^{5}$ In 2004 this variable was not collected. In order to address this gap, the missing 2004 values were replaced by the mean of the 2003 and 2005 values.
} 
temporal effects. Appendix A features a table with the means, correlations, standard deviations and Variance Inflation Factor (VIF) values of each variable.

The highest correlation is 0.43 and the maximum VIF value is 1.43 . Both values are far below the problematic level of 0.75 (Tsui et al., 1995) and 10 (Neter et al., 1996), respectively. Therefore, there are no serious multicollinearity problems in the models.

\section{Results and Discussion}

As noted, this article aims to observe if the OI practices have an inverted U-shape effect on innovation performance and assess if $\mathrm{FnB}$ companies will have the same effect but with a lesser degree of openness. In order to meet with the first goal, in Table 1 we present the estimates of the random effects Logit and Tobit models for the four dimensions of innovation performance.

In models 1.A and 1.B we can observe that the breadth and depth of external information source use has a positive and significant effect while the squared term has a negative and significant effect, confirming the hypothesised inverted U-shape. However, when we look into the new-to-the-firm and new-to-the-market dimensions, the inverted U-shape is only present for the latter with breadth. That is, due to the complexity of managing OI activities, too much informal openness could have a negative impact on the probability of obtaining product or process innovation and a linear impact on incremental innovations. These results are in line with those of Chiang and Hung (2010). As for radical innovation, an extensive usage of information sources (breadth) will produce negative effects on innovation performance, while the use of important information sources (depth) will have a linear effect. Thus, relying strongly on external information sources could reduce the probability to innovate but the innovations achieved will be more radical. As a consequence, we can partially confirm hypothesis 1a for product and process innovation.

\section{INSERT TABLE 1 HERE}

In hypothesis $2 \mathrm{a}$ we stressed the inverted U-shape effect for cooperation agreements. This hypothesis can be confirmed for both product and process innovations and for the new-to-the- 
market innovations (see models 1.A, 1.B and 1.D). Contrary to Nieto and Santamaría (2007), for new-to-the-firm (model 1.C) innovations cooperation breath seems to have a linear effect on the share of incremental innovations. For the third OI dimension, external R\&D expenditure, we observe the same pattern as for cooperation agreements. The argued inverted U-shape effect is present for product, process and new-to-the-market innovations but external R\&D seems not to affect the share of sales due to new-to-the-firm innovations. Therefore, hypotheses $3 \mathrm{a}$ can be partially supported. As model 1.D indicates, FnB firms have a lower likelihood of high turnover due to new-to-the-market products. That is, food firms are less innovative than other Spanish firms in terms of innovation novelty. Previous studies have also reported lower innovation output in the FnB sector (Garcia and Burns, 1999).

As for the control variables used, we can conclude that absorptive capacity has a positive and significant influence on the achievement of product, new-to-the-firm and new-to-the-market innovations but, unexpectedly, a negative influence in the development of process innovation. This might be due to the fact that process innovations are less dependent on firms' $R \& D$ internal capacity given that they are based on activities such as the acquisition of new machinery or the implementation of a new distribution method, for instance.

As noted, increased spending on innovation activities does not make firms any more innovative in terms of product and process. Further, innovation expenditure has a negative and significant effect on the new-to-the-firm variable but a positive effect on new-to-the-market innovations. This might indicate that less novelty innovations might not be as dependent on generic innovation activities such as $R \& D$ activities, $R \& D$ staff or new machinery, as they are on the daily routines that are achieved in other departments of the firm.

On the other hand, the Schumpeterian Hypothesis — which posits that large firms are more innovative thanks to the economies of scale in R\&D and the larger store of technological knowledge and capabilities — is confirmed when we look into the product and process innovations. 
The larger the firm, the higher its probabilities to innovate. Nevertheless, the negative and significant size coefficient in model 2.D indicates that SMEs are more innovative that large firms. This is aligns with previous researchers who argued that SMEs are more innovative thanks to their entrepreneurial attitude, flexibility and dynamism and lack of bureaucracy (e.g., Gregory et al., 2002). We consider that this divergence in our results is, in a way, complementary. Large firms have more probabilities to innovate (product and process) but the ratio of radicalness of those innovations with the total amount of products offered is smaller than in SMEs. In other words, SMEs innovate less but the innovations are more radical than innovations achieved by large firms.

In order to test hypotheses $1 b, 2 b$ and $3 b$ we projected the OI practices interaction effect models and FnB firms as presented in Table 2. In these hypotheses we argued that FnB firms would have the inverted U-shape as the rest of firms but that the threshold would be achieved with a lesser openness due to lack of absorptive capacity and their low-tech, SME-predominant, fragmented industry and value-chain integration industry profile.

\section{-INSERT TABLE 2 HERE-}

Model 2.A in Table 2 indicates that there are no significant differences in the effect of OI activities for FnB firms in terms of product innovation. Observe how neither the FnB control variable nor the interaction terms are significant, indicating that the slope of the inverted U-shape is exactly the same for $\mathrm{FnB}$ as for the rest of firms. However, in the case of process innovations (model 2.C) we observe that the $F n B$ variable is significant and also the interaction terms of breadth*FnB and breadth ${ }^{2} F n B$. This indicates that the slope of the OI effect in FnB is different than the rest of the companies. In order to have a deeper understanding, we graph the slopes and present them in Graph 1a. As observed, both slopes have the hypothesised inverted U-shape form. This graph shows that when the food firms increase the number of external information sources (breadth) in their innovation activities, they achieve the optimum number of external information sources sooner than the rest of Spanish firms. Nevertheless, the use of an excessive number of 
information sources will cause negative consequences for process innovation sooner than in the rest of Spanish firms. While FnB firms achieve the maximum likelihood of obtaining process innovation with 7 external information sources (breadth) the rest of the Spanish firms achieve it with 12. This might be related to the fact that food firms incur greater monitoring and management costs than the rest of Spanish firms due to an excessive use of knowledge research because their interest is on less complex innovation output.

\section{- INSERT GRAPHIC 1 HERE-}

In the rest of OI dimensions in model 2.B, although the interaction effect is not significant (i.e., $\left.d^{2} t^{*} F n B\right)$ the $F n B$ control variable is positive and significant, indicating that the slope has the same shape but above the rest of firms. See in Graph 1.b how the optimal number of important sources is around five for both groups but the probability for obtaining process innovations with the optimal degree of depth is higher for FnB firms. This pattern is repeated for cooperation breadth and external R\&D where their optimal level is around 6 partners and $25 \%$, respectively.

Models 2.C and 2.D present the estimates of the random effects of the Tobit model where we verify the effect of OI activities on the percentage of sales due to new-to-the-market and new-to-the-firm products. We can observe that food firms benefit from openness in the same proportion as the rest of the Spanish firms. Therefore, hypotheses $1 b, 2 b$ and $3 b$ are partially supported for the innovation performance measured as the percentage of sales due to new-to-the-market and new-to-the-firm products since OI activities in FnB firms have an inverted U-shape on firms' innovation performance but the threshold is the same for both groups.

\section{Conclusion}

In recent years there has been a growing interest in the literature for measuring the consequences of firms adopting an Open Innovation strategy. Previous research on this topic involved multi-country and multi-sector studies focused primarily on technologically intensive sectors. This study uses a 
sample of Spanish firms with a focus on the FnB industry, which, despite a poor innovation record, is currently transitioning towards a situation in which innovation can eventually play a key role. The options this sector faces include OI activities that fit very well into an industry characterised by a chain structure (food chain) and a predominance of SMEs.

This study supports and extends the findings of Laursen and Salter (2006) and Berchicci (2013) about the inverted U-shape relationship between OI practices and innovative performance. For the new-to-the-market measures we confirm this relationship for the breadth, cooperation breadth and external $R \& D$ parameters. We also conclude that this relationship still applies for product and process innovation achievement. Therefore, high degrees of formal and informal openness are detrimental for developing innovation and for appropriating their returns. This might be the case because an excessive OI can lead firms to fall into a disproportionate use of external knowledge research, an undue management burden caused by a high number of partners and external costs which will in turn cause time and management problems negatively affecting innovative performance. The main finding of this research is that FnB firms show an inverted U-shape relationship between open innovation practices and performance but the optimal number of external sources is smaller than the rest of the firms in terms of process innovation. In other words, the FnB industry does benefit from OI activities but - due to the specific industry features such as lowtech, mostly SMEs and high integration - too much openness would be more detrimental than for non-FnB industries.

In conclusion, this study has revealed that, contrary to the traditional view of the FnB sector as a low-innovation industry, this sector actually has a strong commitment to OI practices. These results may suggest that OI practices can potentially benefit the industry and other sectors alike, but a culture of innovation is required if they are to have a positive impact on innovation performance. In this sense, our estimates highlighted the crucial role of absorptive capacity in order to increase innovation performance in terms of new product development and rate of sales driven from 
innovative products. Therefore, firms must combine both internal and external knowledge in order to gain competitive advantage through innovation.

This study also contributes to the literature since the results presented are based on a large sample and were estimated using panel data. In contrast to previous related studies (i.e., Laursen and Salter, 2006; Berchicci, 2013) our data structure allows obtaining more robust results and validating the causal inference of OI practices on innovation performance since models are estimated using panel data and OI variables in the model are lagged. The paper is also helpful to remind managers that openness is not the only solution. Too much openness could lead firms to an over-dependency on their suppliers, thus losing technological expertise and absorptive capacity in the long run (Bertrand, 2009; Xu et al., 2012) thus harming innovation performance. This paper shows FnB firm managers that their firms should concentrate on few external information sources if their goal is to achieve process innovations. Managers should be very precise when selecting their sources as too many sources will damage their ability to achieve process innovations.

This study is not free of limitations and some of them could be addressed by future research. First, the focus of this paper was to observe the effects of OI on firms' innovation performance and no consideration was given to the drivers that foster food firms to engage, or not, in OI activities. A possible solution to this would be to perform a two-step Heckman selection model, in which the first step is to observe whether food firms are more or less prone to openness, due to the aforementioned specificities, and in the second step make analyse the effect of OI on firm performance.

Second, the PITEC sample does not allow controlling if the information used (or cooperation with suppliers, for example) was achieved with only one or more agents and whether it was used more than once during the year. Developing an in-depth case study analysis might be helpful to clarify this issue and shed more light into OI literature. 
Finally, in order to gain deeper knowledge of the effects of OI activities, research is needed to focus on the role of outbound OI activities, on the drivers that lead firms to follow this strategy and its consequences. 


\section{REFERENCES}

Abecassis-Moedas, C., and Mahmoud-Jouini, S.B. (2008), "Absorptive capacity and sourcerecipient complementarity in designing new products: An empirically derived framework", The Journal of Product Innovation Management, Vol.25, pp.473-490.

Acosta, M., Coronado, D. and Ferrándiz, E. (2013), "Trends in the acquisition of external knowledge for innovation in the food industry", Open Innovation in the food and beverage industry. Woodhead Publishing Limited. Cambridge. UK.

Alarcón, S. and Sánchez, M. (2013), "External and Internal R\&D, Capital Investment and Business Performance in the Spanish Agri-Food Industry", Journal of Agricultural Economics, Vol.64 No.3, pp. 654-675.

Arnalte, E. and Ortiz, D. (2011), "Breaking down the growth of family farms: A case study of an intensive Mediterranean agriculture", Agricultural Systems, Vol.114, pp. 500-511.

Arranz, N., and Fdez de Arroyabe, J. C. (2008), "The choice of partners in R\&D cooperation: An empirical analysis of Spanish firms", Technovation, Vol.28 No.1, 88-100

Baum, C. (2006), “An introduction to modern econometrics using Stata”. Stata Press, College Station, Texas.

Bayona-Sáez, C. and García-Marco, T. (2010), “Assessing the effectiveness of the Eureka program". Research Policy, Vol.39, pp. 1375-1386

Bayona-Sáez, C., García-Marco, T., Sánchez-García, M., and Cruz-Cázares, C. (2013), “The effects of open innovation practices of Spanish agri-food firms' on their innovation performance", Open innovation in the food and beverage industry. Woodhead Publishing, Chapter. 5 pp. 74-93

Beckeman, M. and Skjöldebrand, C. (2007), "Clusters/networks promote food innovations". Journal of Food Engineering, Vol.79, pp.1418-1425.

Belderbos R., Carree, M. and Lokshin, B. (2004), "Cooperative R\&D and firm Performance", Research Policy, Vol.33 No.10, pp. 1477-1492.

Beneito, P. (2006), "The innovative performance of in-house and contracted R\&D in terms of patents and utility models", Research Policy, Vol. 35 No.4, pp. 502-537.

Berchicci, L. (2013), "Towards an open R\&D system: internal R\&D investment, external knowledge acquisition and innovative performance", Research Policy, Vol. 42, pp. 117-127.

Bigliardi, B. and Galati, F. (2012), "Models of adoption of open innovation within the food industry", Trends in Food Science \& Technology. Vol. 30 No.1, 16-26.

Boehlje, M., Roucan-Kane, M. and Bröring, S. (2011), "Future agribusiness challenges: Strategic uncertainty, innovation and structural change", International Food and Agribusiness Management Review, Vol.14 No.5, 53-82.

Bradley, S. W., Wiklund, J. and Shepherd, D.A. (2010), "Swinging a double-edged sword: the effect of slack on entrepreneurial management and growth", Journal of Business Venturing, Vol. 26 No.5, pp. 537-554.

Capitanio, F., Coppola, A. and Pascucci, S. (2009) "Indications for drivers of innovation in the food sector”, British Food Journal, Vol.111 No.8, pp. 820-838.

Capitanio, F., Coppola, A. and Pascucci, S. (2010), "Product and process innovation in the Italian food industry", Agribusiness, Vol.26 No.4, pp. 503-518.

Costa, A.I.A. and Jongen, W.M.F. (2006), "New insights into consumer-led food product development", Trends in Food Science and Technology, Vol.17 No.8, p. 457. 
Chen, Y. and Yuan, Y. (2007), "The innovation strategy of firms: empirical evidence from the Chinese high-tech industry", Journal of Technology Management in China, Vol.2 No.2, 145-153.

Chesbrough, H. (2003), "Open innovation: the new imperative for creating and profiting from technology", Harvard Business School Press, Boston, MA.

Chesbrough, H., Vanhaverbeke, W. and West, J. (2006), "Open innovation: Researching a new paradigm", Oxford University Press, New York.

Chiang, Y-H. and Hung, K.P. (2010), "Exploring open search strategies and perceived innovation performance from the perspective of inter-organizational knowledge flows", $R \& D$ Management, Vol.40 No.3, pp. 292-299.

Cohen, W.M., Levinthal, D. (1990), “Absorptive capacity: A new perspective on learning and innovation”, Administrative Science Quarterly 35, no. 1: 128-42.

Cotec, (2010), "Panel de innovación tecnológica PITEC. Revisión de 2010”, Ed: Fundación Cotec para la Innovación tecnológica.

Cruz-Cázares, C., Bayona-Sáez, C. and García-Marco, T. (2010), "R\&D Strategies And Firm Innovative Performance: A Panel Data Analysis", International Journal of Innovation Management, Vol.14 No.6, 1013-1045.

Cruz-Cázares, C., Berends, J.J., Smits, A., Reymen, I., Bayona-Sáez, C., and García-Marco, T. (2012), "BMOI Report: A regional comparison of open innovation practices". TU/e Printservice, 2012.

Dahlander, L. and Gann, D.M. (2010), "How open is innovation?" Research Policy, Vol.39 No.6, 699-709.

Ebersberger, B., Bloch, C., Herstad, S. and Van de Velde, E. (2012), "Open Innovation practices and their effect on innovation performance", International Journal of Innovation and Technology Management, Vol.9, No.6, pp.1-23

Eisenhardt, K.M. and Martin, J. (2000), “Dynamic Capabilities: What are they?", Strategic Management Journal, Vol. 21, pp. 1105-1121

Escribano, A., Fosfuri, A. and Tribó, J.A. (2009), "Managing external knowledge flows: The moderating role of absorptive capacity", Research Policy, Vol.38 No.1, 96-105.

Eurostat (2015) Structural business statistics.

Eurostat (2015). Agricultural census in Spain. Available at: http://ec.europa.eu/eurostat/statisticsexplained/index.php/Agricultural_census_in_Spain\#Key_indicators.

Faems, D., De Visser, M., Andries, P., and Van Looy, B. (2010), "Technology Alliance Portfolios and Financial Performance: Value-Enhancing and Cost-Increasing Effects of Open Innovation", Journal of Product Innovation Management, Vol.27 No.6, 785-796.

Fey, C.F. and Birkinshaw, J. (2005), "External sources of knowledge, governance mode, and R\&D Performance", Journal of Management, Vol.31 No.4, 597-621.

FoodDrinkEurope (2012-13-14), Data \& Trends of the European Food and Drink Industry. Brussels Belgium.

Fortuin, F. T. and Omta, S.O. (2009), "Innovation drivers and barriers in food processing", British Food Journal, 111(8), 839-851. 
Galizzi, G. and Venturini, L. (1996), "Product innovation in the food industry: Nature, characteristics and determinants". In G. Galizzi, \& L. Venturini (Eds.), Economics of innovation: The case of food industry (pp. 133-156). Heiderlberg: Physica-Verlag.

García-Martínez, M. and Burns, J. (1999), "Sources of technological development in the Spanish food and drink industry. A "supplier dominated” industry?", Agribusiness, Vol.15 No.4, 431-448.

Gassmann, O. and Enkel, E. (2004), "Towards a theory of open innovation: three core process archetypes", In R\&D Management Conference (Vol. 6), July.

Gianiodis, P. T., Ellis, S.C. and Secchi, E. (2010), "Advancing a typology of open innovation", International Journal of Innovation Management, Vol.14 No.4, 531-572.

Gregory N.S, Greis, N.P. and Fischer W.F. (2002), "Firm size and dynamic technological innovation", Technovation, Vol.22 No. 9, pp. 537-549.

Grunert, K.G., Jensen, B.B., Sonne, A.M., Brunso, K., Byrne, D.V., Clausen, C., Friis, A., Holm, L., Hyldig, G., Kristensen, N.H., Lettl, C. and Scholderer, J. (2008), "User oriented innovation in the food sector: relevant streams of research and agenda for future work", Trends in Food Science and Technology, Vol.19, pp. 590-602.

Hoffmann, W.H. (2005), "How to Manage a Portfolio of Alliances", Long Range Planning, Vol.38 No.2, pp. 121-143.

Huang, F. and Rice, J. (2012), "Openness in product and process innovation", International Journal of Innovation Management, Vol.16 No.4, pp.1-24 pages.

Huizingh, E. (2011), "Open innovation: State of the art and future perspectives", Technovation, Vol.31 No.1, pp.2-9.

Jones, G.K., Lanctot, A. and Teegen, H.J (2001), "Determinants and performance impacts of external technology acquisition". Journal of Business Venturing, Vol.16 No.3, pp. 255-283.

Laursen, K. and Salter, A. (2006), "Open for innovation: the role of openness in explaining innovation performance among U.K. manufacturing firms", Strategic Management Journal, Vol. 27, 131-150.

Lee, S., Park, G., Yoon, B. and Park, J. (2010), "Open innovation in SMEs-An intermediated network model”, Research Policy, Vol.39 No.2, pp. 290-300.

Lichtenthaler, U. (2011), “Open innovation: past research, current debates, and future directions", Academy of Management Perspectives, Vol. 25, pp. 75-93.

Lybbert, T.J. and Sumner, D.A. (2012), "Agricultural technologies for climate change in developing countries: policy options for innovation and technology diffusion”, Food Policy, Vol.37, pp.114123.

Mairesse, J. and Mohnen, P. (2010), "Using innovations surveys for econometric analysis", In: Hall, B. H. \& Rosenberg, N. (eds), Handbook of the Economics of Innovation. Amsterdam: Elsevier B.V., pp.1129-1155

Neter, J., Kutner, M.H., Nachtsheim, C.J. and Wasserman, W. (1996), “Applied linear regression models. Third Edition", Times Mirror Higher Education Group, Chicago, Illinois, USA.

Nieto, M.J. and Santamaria, L. (2007), "The importance of diverse collaborative networks for the novelty of product innovation", Technovation, Vol.27, pp.367-377

Noordman, W.H. and Meijer, E.M. (2013), "Open Innovation in the food and beverage industry". Woodhead Publishing Limited. Cambridge. UK.

OECD (2009), “OECD Rural Policy Reviews: Spain”, OECD Publishing. Paris.

OECD (2014) "Innovation and modernizing the Rural Economy”, Rural Policy Reviews. 
OECD (1997) "Proposed guidelines for collecting and interpreting technological innovation data: Oslo manual", OECD, Publishing. 2nd (revised) Edition.

Rama, R. (1996), "Empirical study on sources of innovation in international food and beverages industry", Agribusiness, Vol.12 No.2, pp.123-134.

Rama, R. (2008), "Handbook of innovation in the food and drink industry", New York. Haworth Press.

Santamaría, L., Nieto, M.J. and Barge-Gil, A. (2009). Beyond formal R\&D: taking advantage of other sources of innovation in low- and medium technology industries. Research Policy, Vol.38 No.3, pp.507-517.

Sarkar, S. and Costa, A.I. (2008). Dynamics of open innovation in the food industry. Trends in Food Science \& Technology, Vol.19 No.11, pp.574-580.

Sofka, W. and Grimpe, C. (2010). Specialized search and innovation performance - evidence across Europe. $R \& D$ Management, Vol.40 No.3, pp.310-323.

Spithoven, A., Clarysse, B. and Knockaert, M. (2010). Building absorptive capacity to organise inbound open innovation in traditional industries. Technovation, Vol.30, pp.130-141.

Tomlinson, P.R. (2010). Co-operative ties and innovation: some new evidence for UK manufacturing. Research Policy 39, 762-775.

Tsai, K. and Wang, J. (2009). External technology sourcing and innovation performance in LMT sectors: An analysis based on the Taiwanese Technological Innovation Survey. Research Policy, Vol.38, No.3, pp. 518-526.

Tsui, A., Ashford, S., Clair, L. and Xin, K. (1995), Dealing with discrepant expectations: response strategies and managerial effectiveness. Academy of Management Journal, Vol.38, pp.1515-43

Vanhaverbeke, W. and Cloodt, M. (2006), "Open innovation in value networks", in Chesbrough, H., Vanhaverbeke, W. and West, J. (Eds), Open Innovation Researching a New Paradigm, Oxford University Press, Oxford

Vanhaverbeke, W.P.M., De Rochemont, M.H., Meijer, E. and Roijakkers, A.H.W.M. (2007), “Open innovation in the agri-food sector", Research paper commissioned by TransForum.

Veugelers, R. and Cassiman, B. (2006), "In search of complementarity in innovation strategy: Internal R\&D and external knowledge acquisition", Management Science, Vol.52, No.1, 68-82. doi:10.1287/mnsc.1050.0470. 
Figure 1. Conceptual Model

\begin{tabular}{|c|c|c|}
\hline \multicolumn{3}{|c|}{ Competitive Environment: food sector } \\
\hline $\begin{array}{l}\text { Open Innovation } \\
\text { strategy } \\
\mathrm{t}-1 \\
\text { (Inbound activities: } \\
\text { formal and } \\
\text { informal) }\end{array}$ & H1, H2, H3 & $\begin{array}{c}\text { Innovative } \\
\text { Performance } \\
\mathrm{t} \\
\text { (Product and } \\
\text { process innovation; } \\
\text { new-to-the-market } \\
\text { and new-to-the- } \\
\text { firm products) }\end{array}$ \\
\hline & control & \\
\hline
\end{tabular}


Table 1. Testing hypotheses $1 a, 2 a$ and $3 a$ - inverted $U$-shape effect of OI on innovation performance-

\begin{tabular}{|c|c|c|c|c|}
\hline & $\begin{array}{l}\text { 1.A Product } \\
\text { innovation }\end{array}$ & $\begin{array}{l}\text { 1.B Process } \\
\text { Innovation }\end{array}$ & $\begin{array}{c}\text { 1.C New-to-the- } \\
\text { firm }\end{array}$ & $\begin{array}{c}\text { 1.D New-to-the- } \\
\text { market }\end{array}$ \\
\hline \multirow[t]{2}{*}{ Breadth ${ }_{t-1}$} & $0.093^{* * *}$ & $0.101^{* * *}$ & $0.662^{* *}$ & $1.436^{* * *}$ \\
\hline & $(0.022)$ & $(0.021)$ & $(0.316)$ & $(0.339)$ \\
\hline \multirow[t]{2}{*}{ Depth $_{\mathrm{t}-1}$} & $0.123^{* * *}$ & $0.128^{* * *}$ & 0.370 & $0.865^{* *}$ \\
\hline & $(0.029)$ & $(0.028)$ & $(0.382)$ & $(0.388)$ \\
\hline \multirow[t]{2}{*}{ Cooperation breadth -1} & $0.281^{* * *}$ & $0.224^{* * *}$ & $1.035^{* *}$ & $2.438^{* * *}$ \\
\hline & $(0.043)$ & $(0.041)$ & $(0.523)$ & $(0.527)$ \\
\hline \multirow[t]{2}{*}{ External $R \& D_{t-1}$} & $0.009^{* * *}$ & $0.009^{* * *}$ & 0.030 & $0.167^{* * *}$ \\
\hline & $(0.002)$ & $(0.003)$ & $(0.035)$ & $(0.036)$ \\
\hline \multirow[t]{2}{*}{ Breadth $^{2}{ }_{\mathrm{t}-1}$} & $-0.003^{*}$ & $-0.005^{* *}$ & -0.016 & $-0.062^{* *}$ \\
\hline & $(0.002)$ & $(0.002)$ & $(0.027)$ & $(0.029)$ \\
\hline \multirow[t]{2}{*}{ Depth $^{2}{ }_{t-1}$} & $-0.009^{* *}$ & $-0.0115^{* * *}$ & 0.0071 & 0.007 \\
\hline & $(0.005)$ & $(0.004)$ & $(0.603)$ & $(0.060)$ \\
\hline \multirow[t]{2}{*}{ Cooperation breadth ${ }_{\mathrm{t}-1}^{2}$} & $-0.028^{* *}$ & $-0.182^{* *}$ & -0.171 & $-0.182^{*}$ \\
\hline & $(0.010)$ & $(0.009)$ & $(0.130)$ & $(0.06)$ \\
\hline \multirow[t]{2}{*}{ External $R \& D^{2}{ }_{t-1}$} & $-0.0001^{* * *}$ & $-0.0002^{* * *}$ & -0.0006 & $-0.002^{* * *}$ \\
\hline & $(0.000)$ & $(0.000)$ & $(0.0004)$ & $(0.000)$ \\
\hline \multirow[t]{2}{*}{ Absorptive capacity. $\mathrm{t}-1$} & $0.426^{* * *}$ & $-0.251^{* * *}$ & $2.979^{* * *}$ & $7.210^{* * *}$ \\
\hline & $(0.024)$ & $(0.237)$ & $(0.338)$ & $(0.365)$ \\
\hline \multirow[t]{2}{*}{ Innovation expenditure.t-1 } & -0.0015 & -0.009 & $-0.292^{*}$ & $0.543^{* * *}$ \\
\hline & $(0.011)$ & $(0.011)$ & $(0.172)$ & $(0.156)$ \\
\hline \multirow[t]{2}{*}{ Size } & $0.059^{* * *}$ & $0.575^{* * *}$ & -0.202 & $-1.554^{* * *}$ \\
\hline & $(0.021)$ & $(0.021)$ & $(0.285)$ & $(0.299)$ \\
\hline \multirow[t]{2}{*}{ Food } & -0.091 & $0.868^{* * *}$ & -1.288 & $-6.357^{*}$ \\
\hline & $(0.137)$ & $(0.000)$ & $(1.855)$ & (3.787) \\
\hline year dummies & Yes & Yes & Yes & Yes \\
\hline \multirow[t]{2}{*}{ cons } & 0.079 & $-1.872^{* * *}$ & -13.522 & $-27.631^{* * *}$ \\
\hline & $(0.109)$ & $(0.106)$ & $(1.551)$ & $(1.664)$ \\
\hline \multirow[t]{2}{*}{ Insig2u } & $2.350 * * *$ & $2.126^{* * *}$ & & \\
\hline & $(0.033)$ & $(0.032$ & & \\
\hline $\mathrm{N}$ & 51695 & 51695 & & \\
\hline Log likelihood & -22484.44 & -22651.4 & -139902 & -113154.9 \\
\hline chi2 & 1392.3 & 1681.4 & 301.23 & 954.73 \\
\hline Rho & 0.761 & 0.718 & 0.583 & 0.619 \\
\hline \multirow[t]{2}{*}{ sigma_u } & 3.239 & 2.894 & $43.606^{* * *}$ & $44.35^{* * *}$ \\
\hline & & & $(0.500)$ & $(0.000)$ \\
\hline \multirow[t]{2}{*}{ Sigma e } & & & $38.873^{* * *}$ & $34.79^{* * *}$ \\
\hline & & & $(0.199)$ & $(0.2088)$ \\
\hline
\end{tabular}


Table 2. Testing hypotheses $1 b, \mathbf{2 b}$ and $3 b$ - inverted U-shape effect of OI on innovation performance for food firms and lesser threshold for OI negative effects-

\begin{tabular}{|c|c|c|c|c|}
\hline & $\begin{array}{l}\text { 2.A Product } \\
\text { Innovations }\end{array}$ & $\begin{array}{l}\text { 2.B Process } \\
\text { Innovations }\end{array}$ & $\begin{array}{l}\text { 2.C Innovations } \\
\text { new-to-the- firm }\end{array}$ & $\begin{array}{c}\text { 2.D Innovations } \\
\text { new-to-the-market }\end{array}$ \\
\hline \multirow[t]{2}{*}{ Breadth $\mathrm{t}-1$} & $0.0884^{* * *}$ & $0.0834^{* * *}$ & $0.693^{* *}$ & $1.481^{* * *}$ \\
\hline & $(0.022)$ & $(0.022)$ & $(0.326)$ & $(0.348)$ \\
\hline \multirow[t]{2}{*}{ Depth $_{\mathrm{t}-1}$} & $0.124^{* * *}$ & $0.134^{* * *}$ & 0.276 & $0.947^{* *}$ \\
\hline & $(0.029)$ & $(0.028)$ & $(0.396)$ & $(0.401)$ \\
\hline \multirow[t]{2}{*}{ Cooperation Breadth -1} & $0.295^{* * *}$ & $0.219^{* * *}$ & $1.036^{*}$ & $2.438^{* * *}$ \\
\hline & $(0.044)$ & $(0.042)$ & $(0.540)$ & $(0.538)$ \\
\hline \multirow[t]{2}{*}{ External $R \& D_{t-1}$} & $0.0081^{* * *}$ & $0.0099^{* * *}$ & 0.014 & $0.178^{* * *}$ \\
\hline & $(0.002)$ & $(0.002)$ & $(0.037)$ & $(0.037)$ \\
\hline \multirow[t]{2}{*}{ Breadth $^{2} \mathrm{t}-1$} & -0.00282 & $-0.00349^{*}$ & -0.0175 & $-0.067^{* *}$ \\
\hline & $(0.002)$ & $(0.002)$ & $(0.028)$ & $(0.030)$ \\
\hline \multirow[t]{2}{*}{ Depth $^{2}{ }_{t-1}$} & $-0.009^{* *}$ & $-0.0126^{* * *}$ & 0.00442 & 0.018 \\
\hline & $(0.004)$ & $(0.004)$ & $(0.062)$ & $(0.061)$ \\
\hline \multirow{2}{*}{ Cooperation Breadth ${ }^{2}{ }_{t-1}$} & $-0.0230^{* *}$ & $-0.0178^{*}$ & -0.156 & -0.175 \\
\hline & $(0.010)$ & $(0.009)$ & $(0.116)$ & $(0.113)$ \\
\hline \multirow[t]{2}{*}{ External R\&D ${ }_{t-1}$} & $-0.0009^{* * *}$ & $-0.0002^{* * *}$ & -0.001 & $-0.002^{* * *}$ \\
\hline & $(0.000)$ & $(0.000)$ & $(0.001)$ & $(0.001)$ \\
\hline \multirow{2}{*}{ Breadth $_{\mathrm{t}-1} * \mathrm{FnB}$} & 0.0604 & $0.282^{* * *}$ & -0.381 & -0.817 \\
\hline & $(0.081)$ & $(0.083)$ & (1.133) & $(1.230)$ \\
\hline \multirow[t]{2}{*}{ Depth $_{\mathrm{t}-1} * \mathrm{FnB}$} & -0.0276 & -0.0953 & 1053 & -0.835 \\
\hline & $(0.118)$ & $(0.121)$ & $(1.514)$ & $(1.588)$ \\
\hline \multirow[t]{2}{*}{ Cooperation breadth $\mathrm{t}-1^{*} \mathrm{FnB}$} & -0.169 & 0.0648 & 0.379 & 0.266 \\
\hline & $(0.168)$ & $(0.192)$ & $(2.002)$ & $(2.063)$ \\
\hline \multirow[t]{2}{*}{ External $R \& D_{t-1} * F n B$} & 0.00812 & -0.0089 & 0.184 & -0.152 \\
\hline & $(0.009)$ & $(0.010)$ & $(0.131)$ & $(0.137)$ \\
\hline \multirow[t]{2}{*}{ Breadth $^{2}{ }_{\mathrm{t}-1} * \mathrm{FnB}$} & -0.00612 & $-0.0239^{* * *}$ & 0.015 & 0.0913 \\
\hline & $(0.007)$ & $(0.007)$ & $(0.102)$ & $(0.109)$ \\
\hline \multirow[t]{2}{*}{ Depth $_{\mathrm{t}-1} * \mathrm{FnB}$} & 0.00948 & 0.0199 & 0.075 & -0.262 \\
\hline & $(0.020)$ & $(0.021)$ & $(0.247)$ & $(0.263)$ \\
\hline \multirow[t]{2}{*}{ Cooperation breadth ${ }^{2}{ }_{\mathrm{t}-1} * \mathrm{FnB}$} & 0.00829 & 0.00925 & -0.352 & -0.236 \\
\hline & $(0.043)$ & $(0.056)$ & $(0.489)$ & $(0.503)$ \\
\hline \multirow[t]{2}{*}{ External R\&D ${ }_{\mathrm{t}-1} * \mathrm{FnB}$} & -0.00016 & 0.000062 & $-0.003^{*}$ & 0.001 \\
\hline & $(0.0001)$ & $(0.0001)$ & $(0.001)$ & $(0.002)$ \\
\hline \multirow[t]{2}{*}{ Absorptive capacity $\mathrm{t}-1$} & $0.427^{* * *}$ & $-0.251^{* * *}$ & $2.980^{* * *}$ & $7.211^{* * *}$ \\
\hline & $(0.023)$ & $(0.023)$ & $(0.339)$ & $(0.365)$ \\
\hline \multirow[t]{2}{*}{ Innovation expenditure $\mathrm{t}_{\mathrm{t}-1}$} & -0.00159 & -0.009 & $-0.291^{*}$ & $0.540^{* * *}$ \\
\hline & $(0.011)$ & $(0.010)$ & $(0.174)$ & $(0.156)$ \\
\hline \multirow[t]{2}{*}{ Size } & $0.0591^{* * *}$ & $0.574^{* * *}$ & -0.202 & $-1.537^{* * *}$ \\
\hline & $(0.020)$ & $(0.020)$ & $(0.286)$ & $(0.300)$ \\
\hline \multirow[t]{2}{*}{$\mathrm{FnB}$} & -0.0742 & $0.408^{*}$ & -1.302 & 0.247 \\
\hline & $(0.208)$ & $(0.205)$ & (2.915) & (3.201) \\
\hline year dummies & yes & yes & yes & yes \\
\hline _cons & 0.0787 & $-1.749^{* * *}$ & $-13.53^{* * *}$ & $-28.02^{* * *}$ \\
\hline & $(0.110)$ & $(0.107)$ & $(1.560)$ & $(1.672)$ \\
\hline Insig2u & $2.353^{* * *}$ & $2.126^{* * *}$ & & \\
\hline & $(0.033)$ & $(0.032)$ & & \\
\hline Log likelihood & -22479.6 & -22644.1 & -139897.2 & -113148.7 \\
\hline chi2 & 1399.2 & 1690.6 & 310.6 & 966.9 \\
\hline Rho & 0.762 & 0.718 & 0.583 & 0.619 \\
\hline sigma_u & 3.242 & 2.895 & $43.62^{* * *}$ & $44.37^{* * *}$ \\
\hline & & & $(0.501)$ & $(0.556)$ \\
\hline Sigma e & & & $36.87^{* * *}$ & $34.78^{* * *}$ \\
\hline & & & $(0.199)$ & $(0.209)$ \\
\hline
\end{tabular}


Graphic 1: Slopes for innovation performance and open innovation practices

\section{1.a Breadth and process innovation}

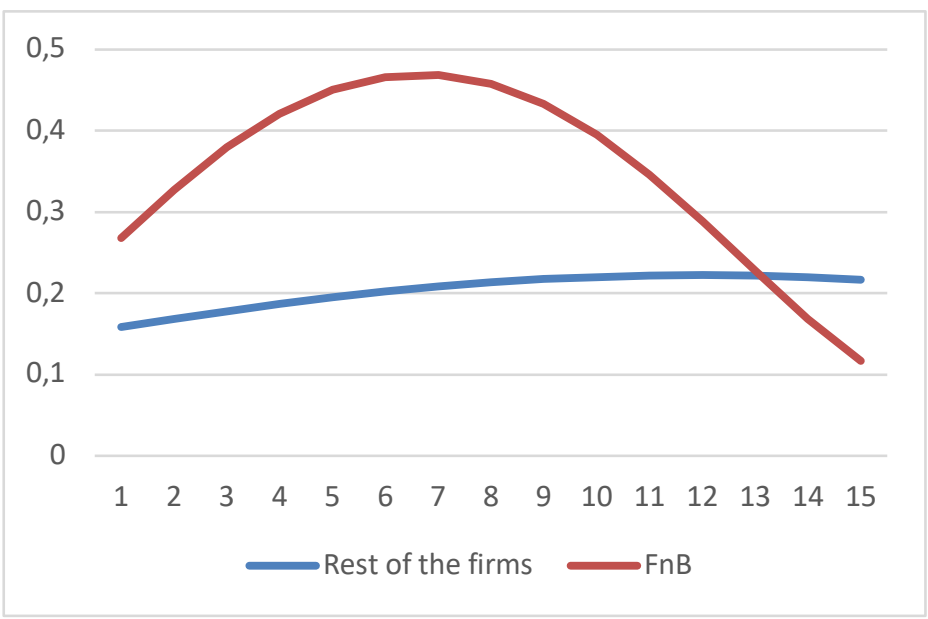

\section{1.b Depth and process innovations}

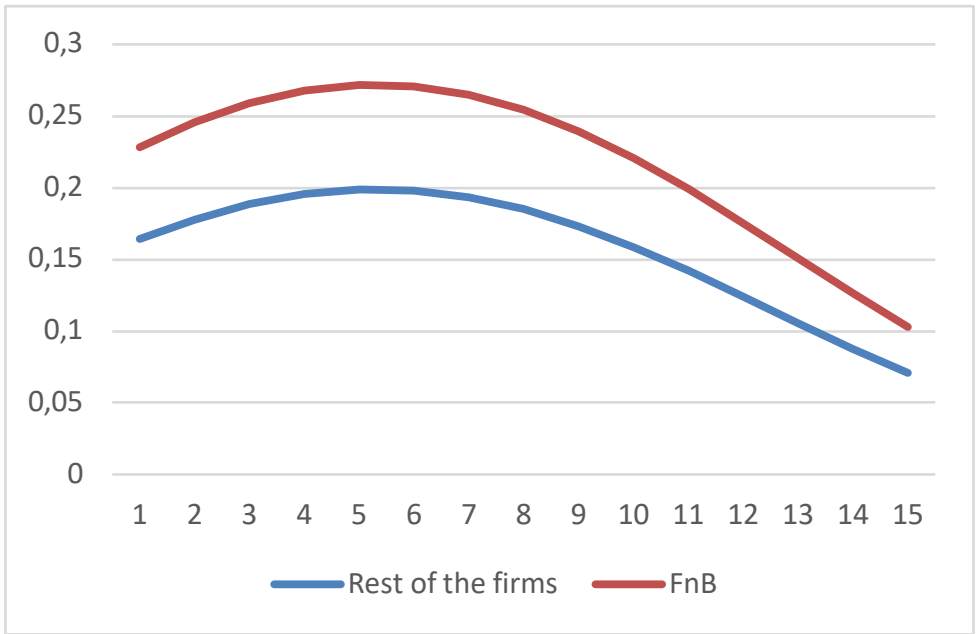


APPENDIX A. Definition, descriptive and correlations of variables

\begin{tabular}{|c|c|c|c|}
\hline VARIABLES & DESCRIPTION & $\begin{array}{c}\text { TYPE OF } \\
\text { VARIABLE }\end{array}$ & VALUES \\
\hline \multicolumn{4}{|c|}{ Dependent Variables } \\
\hline $\begin{array}{l}\text { Product } \\
\text { Innovation }\end{array}$ & The firm has introduced new or significantly improved products. & Binary & $\begin{array}{l}0=\text { no } \\
1=\text { yes }\end{array}$ \\
\hline $\begin{array}{l}\text { Process } \\
\text { Innovation }\end{array}$ & The firm has introduced new or significantly improved processes. & Binary & $\begin{array}{l}0=\text { no } \\
1=\text { yes }\end{array}$ \\
\hline $\begin{array}{l}\text { Sales due to } \\
\text { new-to } \\
\text { the-market } \\
\text { products }\end{array}$ & $\begin{array}{l}\text { The percentage of the firm's sales from products innovations that } \\
\text { were new to the firm's market. }\end{array}$ & Continuous & $0-100 \%$ \\
\hline $\begin{array}{l}\text { Sales due to } \\
\text { new-to } \\
\text { the-firm } \\
\text { products }\end{array}$ & $\begin{array}{l}\text { The percentage of the firm's sales from products innovations that } \\
\text { were only new to the firm }\end{array}$ & Continuous & $0-100 \%$ \\
\hline \multicolumn{4}{|c|}{ Independent Variables } \\
\hline \multicolumn{4}{|l|}{ Open Innovation } \\
\hline Breadth & Number of external sources of information for innovation & Ordinal & $0-10$ \\
\hline Depth & $\begin{array}{l}\text { Number of external sources of information for innovation that firm } \\
\text { uses to a high degree }\end{array}$ & Ordinal & $0-10$ \\
\hline $\begin{array}{l}\text { Cooperation } \\
\text { Breadth }\end{array}$ & $\begin{array}{l}\text { Number of different types of agents with which the firm cooperates } \\
\text { for innovation }\end{array}$ & Ordinal & $0-8$ \\
\hline External R\&D & $\begin{array}{l}\text { The percentage of innovation expenditure that corresponds to } \\
\text { external R\&D activities }\end{array}$ & Continuous & $0-100 \%$ \\
\hline $\begin{array}{l}\text { Absorptive } \\
\text { capacity }\end{array}$ & $\begin{array}{l}\text { Factor loading of the internal R\&D expenditures, percentage of } \\
\text { innovation expenditures dedicated to training employees, type of } \\
R \& D \text { (occasional or continued) and the percentage of employees } \\
\text { dedicated to R\&D activities). }\end{array}$ & Continuous & \\
\hline Agriculture & $\begin{array}{l}\text { The firm belongs to the agriculture industry (agriculture, cattle, } \\
\text { forestry and fishing) }\end{array}$ & Binary & $\begin{array}{l}0=\text { no } \\
1=\text { yes }\end{array}$ \\
\hline Food & $\begin{array}{l}\text { The firm belongs to the food industry (food, beverages, and } \\
\text { tobacco) }\end{array}$ & Binary & $\begin{array}{l}0=\text { no } \\
1=\text { yes }\end{array}$ \\
\hline \multicolumn{4}{|c|}{ Control Variables } \\
\hline $\begin{array}{l}\text { Innovation } \\
\text { Expenditure }\end{array}$ & Innovation expenditure relative to total sales & $\begin{array}{l}\text { Continuous } \\
\text { (simulated) }\end{array}$ & $0-100 \%$ \\
\hline Size & Natural logarithm of number of employees & $\begin{array}{l}\text { Continuous } \\
\text { (simulated) }\end{array}$ & $0-+\infty$ \\
\hline
\end{tabular}


Mean, Standard Deviation, Correlations between variables

\begin{tabular}{|c|c|c|c|c|c|c|c|}
\hline Variables & Mean & Std. Dev. & 1 & 2 & 3 & 4 & 5 \\
\hline 1. Radical innov. & 11.63 & 24.37 & 1 & & & & \\
\hline 2. Incremental innov. & 15.80 & 28.54 & $-0.0535^{*}$ & 1 & & & \\
\hline 3. Product innov. & 0.67 & 0.47 & $0.3345^{*}$ & $0.3882 *$ & 1 & & \\
\hline 4. Process innov. & 0.69 & 0.46 & -0.0006 & -0.0004 & $0.0197 *$ & 1 & \\
\hline 5. Breadth & 5.84 & 3.44 & $0.1160 *$ & $0.0417 *$ & $0.2203 *$ & $0.1042 *$ & 1 \\
\hline 6. Depth & 1.18 & 1.54 & $0.0957 *$ & $0.0333 *$ & $0.1335^{*}$ & $0.0682 *$ & $0.4310^{*}$ \\
\hline 7. Breadth_coop & 0.56 & 1.12 & $0.0866^{*}$ & 0.0103 & $0.1396^{*}$ & $0.1019 *$ & $0.2759 *$ \\
\hline 8. External R\&D & 9.57 & 21.36 & 0.0052 & -0.0038 & -0.0036 & -0.0066 & $0.0973 *$ \\
\hline 9. AbsCap & -0.05 & 1.02 & $0.1626^{*}$ & $0.0537 *$ & $0.2599 *$ & $-0.0271 *$ & $0.3828 *$ \\
\hline 10. Innov. Exp. & 0.21 & 1.82 & $0.0566^{*}$ & $0.0167 *$ & 0.0019 & $-0.0395^{*}$ & $0.0458 *$ \\
\hline 11. Size & 4.09 & 1.63 & $-0.0884 *$ & $-0.0426^{*}$ & -0.000 & $0.1952 *$ & $0.0851 *$ \\
\hline 12. Agriculture & 0.01 & 0.12 & -0.004 & $-0.0255^{*}$ & $-0.0334 *$ & -0.0021 & 0.0082 \\
\hline 13. Food & 0.07 & 0.26 & $-0.0456^{*}$ & -0.0061 & -0.0056 & $0.0616^{*}$ & $0.0258 *$ \\
\hline VIF & & & ---- & ---- & ---- & ---- & 1.43 \\
\hline
\end{tabular}

\begin{tabular}{|c|c|c|c|c|c|c|c|c|}
\hline Variables & 6 & 7 & 8 & 9 & 10 & 11 & 12 & 13 \\
\hline 6. Depth & 1 & & & & & & & \\
\hline 7. Breadth_coop & $\begin{array}{c}0.2470 \\
*\end{array}$ & 1 & & & & & & \\
\hline 8. Internal Info. & $\begin{array}{c}0.0684 \\
*\end{array}$ & $\begin{array}{c}0.1025 \\
*\end{array}$ & 1 & & & & & \\
\hline 9. Internal R\&D & $\begin{array}{c}0.2248 \\
*\end{array}$ & $\begin{array}{c}0.2171 \\
*\end{array}$ & $-0.0786^{*}$ & 1 & & & & \\
\hline 10. External R\&D & $\begin{array}{c}0.0603 \\
*\end{array}$ & $\begin{array}{c}0.0517 \\
*\end{array}$ & 0.0105 & $0.0843 *$ & 1 & & & \\
\hline 11. Innov. Exp. & 0.0078 & $\begin{array}{c}0.1256 \\
*\end{array}$ & $0.0559 *$ & -0.0024 & $-0.0907^{*}$ & 1 & & \\
\hline 12. Size & $\begin{array}{c}0.0140 \\
*\end{array}$ & $\begin{array}{l}0.0211 \\
*\end{array}$ & $0.0168 *$ & $0.0149 *$ & -0.0025 & $-0.0414^{*}$ & 1 & \\
\hline 13. Agrifood & 0.0051 & -0.008 & -0.0014 & $-0.0324 *$ & $-0.0240 *$ & $0.0408 *$ & $-0.0337^{*}$ & 1 \\
\hline VIF & 1.26 & 1.23 & 1.15 & 1.04 & 1.04 & 1.02 & 1.01 & 1.00 \\
\hline
\end{tabular}

